\title{
“O RUGIDO DAS RUAS” EM 15 DE MARÇO \\ DE 2015, NO BRASIL: ACONTECIMENTO, DISCURSO E MEMÓRIA
}

\section{“LE RUGISSEMENT DANS LES RUES” LE 15 MARS 2015, AU BRÉSIL: ÉVÉNEMENT, DISCOURS ET MÉMOIRE}

\author{
Maria do Socorro Aguiar de Oliveira Cavalcante, Fabiano Duarte \\ Machado $^{2}$
}

\author{
"Toda ciência seria supérflua se a forma \\ de manifestação e a essência das coisas \\ coincidissem imediatamente" \\ (MARX CAPITAL LIVRO II)
}

\begin{abstract}
RESUMO: Este trabalho tem por objetivo refletir sobre of funcionamento da memória na disputa dos sentidos engendrados em protestos que irrompem, no Brasil, no dia 15 de março de 2015, contra o governo da presidente Dilma Roussef. Segundo Courtine (1981, p. 48), "Toda produção discursiva faz circular formulações anteriores, [...] que ela repete, transforma, denega... Isto é: em relação às quais produz efeitos de memória." Assim, pela via da Análise do Discurso, ancorada no Materialismo Histórico Dialético e a partir das categorias Condições de Produção e Memória discursiva analisamos o funcionamento de materialidades discursivas produzidas pela imprensa e por participantes envolvidos no 'acontecimento' de 15 de março.
\end{abstract}

PALAVRAS-CHAVE: acontecimento; discurso e memória.

RÉSUMÉ: Ce travail prétend réfléchir sur le fonctionnement de la mémoire dans la dispute des sens engendrés lors des protestations contre le gouvernement de la présidente Dilma Roussef et qui ont fait irruption au Brésil le 15 mars 2015. Selon Courtine (2006, p. 88), "le discours politique est un lieu de mémoire" [...] qui permet de faire ressurgir des énoncés, en favorisant leur disponibilité dès que les besoins de lutte les réclament". Ainsi, par la voie de

1 Doutora em Letras e Linguística pela Universidade Federal de Alagoa. Professora associada 2 da Universidade Federal de Alagoas.

2 Mestre em Educação Brasileira pela Universidade Federal de Alagoas. Professor de História, Educação e Economia do Instituto Federal de Educação, Ciência e Tecnologia de Alagoas. 
l'Analyse du Discours, ancrée dans le Matérialisme Historique Dialectique, on analyse le fonctionnement de la mémoire, dans le cas des matérialités discursives produites para les médias de même que par des participants engagés dans l'événement du 15 mars.

MOTS-CLES: événement; discours; mémoire.

\section{Introdução}

Na perspectiva do materialismo histórico-dialético, todo processo de produção do conhecimento necessita ultrapassar a realidade fenomênica, uma vez que a essência não se dá a conhecer à primeira vista. Nesse processo de aproximação da totalidade do objeto, há que se considerar a importância da História, entendida como processo sempre inconcluso, do agir humano, considerada um campo de batalhas, de disputa de sentidos, de luta de classes. Essa concepção, entretanto, não é hegemônica. Indo de encontro a essa perspectiva do materialismo histórico-dialético constata-se, na última quadra histórica, seja especificamente no meio acadêmico seja na sociedade civil $^{3}$, o modismo hegemonizante da pós-modernidade e suas variáveis que insiste em "reinventar a roda", negando a totalidade, a concretude do real, em especial do ser social.

Essas construções teórico/político/ideológicas apontam em síntese que esse "real", ou seja, o passado, o presente e o futuro, não passam de "linguagem", de "construtos das nossas mentes", e, como tal, devem ser tratados. Negando a possibilidade de acesso à realidade objetiva, relativizam e atomizam as lentes da História e das ciências humanas e sociais, de tal modo, que essas relações se tornam tão "fluídas/líquidas" que seriam incapazes de serem compreendidas, muito menos transformadas/revolucionadas.

Esse modismo/reformismo nos/dos dias atuais, afeta uma grande maioria de sujeitos, na "tentativa de ultrapassar" "ou mesmo de negar" o materialismo histórico-dialético - sua ontologia do ser social, suas teses fundamentais (revolução proletária, emancipação humana, destruição do Estado), e suas análises da totalidade das relações sociais (modo de produção, infra e superestrutura e as formações sociais nacionais) -. As ações desses sujeitos em busca de "novos protagonismos", de "novas mentalidades", de "novas possibilidades de administrar o Estado capitalista", seguem assim, numa luta para constante deter, ressignificar possíveis transforma-

3 Entendemos aqui o conceito de sociedade civil com base em Marx, onde se desenvolvem as relações infra e superestruturais das relações sociais, numa totalidade dialética. 
ções, e estabilizar/hegemonizar o modo de construir a memória coletiva.

Contrapondo-se a essa perspectiva, entendemos ser muito esclarecedora e atual a posição de Marx (2005, p. 52 e 53) a respeito do dinamismo da história e seus fios condutores da posição do sujeito, na dialética do processo de reprodução e transformação das relações de produção, na sociedade de classes.

[...] na produção social da própria vida, os homens contraem relações determinadas, necessárias, independentes de sua vontade, relações de produção estas que correspondem a uma etapa determinada de desenvolvimento das suas forças produtivas materiais. A totalidade dessas relações de produção forma a estrutura econômica da sociedade, a base real sobre a qual se eleva uma superestrutura jurídica e política e à qual correspondem formas determinadas de consciência social. O modo de produção da vida material condiciona o processo em geral da vida social, política e espiritual. Não é a consciência dos homens que determina o seu ser, mas ao contrário é o seu ser social que determina a sua consciência.

Ainda no tocante à questão da possibilidade de transformação das relações sociais, o materialismo histórico-dialético chama a atenção para o processo de objetivação da subjetividade humana e suas mediações em determinadas conjunturas históricas. Trazendo essas reflexões para os dias atuais, percebe-se que as forças produtivas da sociedade atingem tamanho grau de desenvolvimento que entram em choque com a propriedade privada e todo seu aparato ideológico que, de crise em crise, essa deformidade estrutural das relações de produção do capital, dialeticamente, abre as possibilidades por um lado, de revolução social e por outro, perigosamente, de barbárie.

\section{A determinação histórica dos sentidos na AD.}

Neste artigo, nosso objetivo imediato é analisar os efeitos de sentido engendrados em materialidades discursivas desencadeadas pelas manifestações de rua, ocorridas em 15 de março de 2015. Para tanto, acionaremos os pressupostos teóricos e metodológicos da Análise do Discurso, ancorada no Materialismo histórico dialético. A partir dessa perspectiva, consideramos necessário entender que toda produção discursiva é historicamen- 
te determinada, ou seja, não nasce, espontaneamente, de um psiquismo individual; ao contrário, é socialmente produzida, em um determinado momento histórico, para responder às necessidades postas nas relações entre os homens, para produção e reprodução de sua existência, logo, não é gestada num terreno social político e cultural "neutro", uma vez que há interesses antagônicos em jogo. Assim, a discursividade pós-moderna, que emerge das relações capitalistas de produção, constitui uma configuração antagônica e fenomênica do processo social de produção; antagônica não em um sentido particular, mas na sua origem, nas condições sociais de vida dos indivíduos, caracterizando-se assim como uma camisa de força dos curtos circuitos das relações de produção, fundadas na propriedade privada, atuando como um dique para deter as forças produtivas que, dialeticamente, buscam se desenvolver, no interior da sociedade burguesa. Como assevera Marx, (Idem)

[...] Com a transformação da base econômica, toda a enorme superestrutura se transforma com maior ou menor rapidez. $\mathrm{Na}$ consideração de tais transformações é necessário distinguir sempre entre a transformação material das condições econômicas de produção, que pode ser objeto de rigorosa verificação da ciência natural, e as formas jurídicas, políticas, religiosas, artísticas ou filosóficas, em resumo, as formas ideológicas pelas quais os homens tomam consciência desse conflito e o conduzem até ao fim. Assim como não se julga o que um indivíduo é a partir do julgamento que ele se faz de si mesmo, da mesma maneira não se pode julgar uma tal época de transformação a partir de sua própria consciência; ao contrário, é preciso explicar essa consciência a partir das contradições da vida material, a partir do conflito existente entre as forças produtivas sociais e as relações de produção. (Grifo nosso).

Por isso, nas amplas dimensões da luta de classes, na disputa de posições nas ciências humanas e sociais ${ }^{4}$, em especial na arena da História, é possível assistir, nos dias atuais, a um processo frenético de (re)tomada e (re)significação da memória social ${ }^{5}$ como estratégia política de construção

4 Ver PÊCHEUX, P. Posição sindical e tomada de partido nas ciências humanas e sociais. In Análise de Discurso: Michel Pêcheux Textos selecionados: Eni Puccineli Orlandi - Campinas, SP: $4^{a}$ Ed. - Pontes Editores, 2014.

5 Cf. Le Goff, J. História e Memória; tradução Bernardo Leitão - Campinas, SP Editora da UNICAMP, 1990, e HOBSBAWM, Eric. Sobre História. São Paulo: Companhia das Letras, 2002. 
de "novos consensos". Entendemos ser de grande pertinência trazer aqui a posição de Pêcheux (1997, p. 152), que, a partir de numa leitura de Marx, demarca os fundamentos da sua posição quando afirma:

A história é um imenso sistema 'natural-humano' em movimento, cujo motor é a luta de classes [...]. Portanto, a história, ainda uma vez, isto é, a história da luta de classes, isto é, a reprodução/ transformação das relações de classes - com os caracteres infra-estruturais (econômicos) e superestruturais (jurídico-políticos e ideológicos) que lhes correspondem.

A partir de Pêcheux e trazendo essa reflexão para o campo específico da Análise do Discurso, Silva-Sobrinho (2007, p. 46), nos traz contribuições, para o entendimento dessa questão:

A noção de história na $\mathrm{AD}$ é alvo de inúmeras polêmicas. [...] Essa categoria, conforme Pêcheux e Fuchs (1997), está vinculada ao materialismo histórico. Nessa perspectiva, a história não é tida como um sistema sincrônico, tampouco como evolutivo (diacrônico); pelo contrário, essa categoria tem a ver com as relações sociais em determinada formação social. [...] É a partir dessa perspectiva que se compreende a noção de história como o modo pelo qual os homens produzem e reproduzem suas condições materiais de existência no processo de autoconstrução humana.

Esse processo de autoconstrução não seria possível sem o discurso entendido como práxis social e, ontologicamente ancorado no caráter universal e particular da linguagem, como complexo social capaz de mediar a relação dos homens com a natureza e dos homens entre si conectando-se assim aos dois momentos teleológicos (LUKÁCS, 2013, p. 222). Sendo materializado pela linguagem, o discurso é, pois conforme Silva-Sobrinho, um "complexo mediador entre a troca orgânica dos homens com a natureza e das relações dos homens entre si."(Idem, p.48) ou ainda, como dizem (MALDIDIER, NORMAND \& ROBIN, 1997, p. 82). "como uma prática resultante de um conjunto de determinações reguladas em um momento dado por um feixe complexo de relações com outras práticas, discursivas e não discursivas." 
Entendemos esse "conjunto de determinações reguladas em um momento dado, por um feixe complexo de relações" como acontecimento, também definido por Bakhtin (1993) como evento de curta ou longa duração em seu contexto imediato, convocando uma memória histórica das tensões, no espaço da luta de classes. O referido autor (1993, p. 54) também define evento como "movimento, responsavelmente consciente da consciência que transforma a possibilidade na atualidade de uma ação realizada".

Assim, os processos discursivos são constituídos a partir de acontecimentos, numa dada sociedade, produzindo sentidos historicamente determinados. Consequentemente, o estudo dos processos de produção de sentidos exige uma compreensão da sociedade na qual os discursos emergem. É isso que afirma Courtine (2010, p. 163): "se não se tem o saber histórico que permite compreender profundamente a complexidade de todo o assunto analisado, não se compreende nada de nada". Nessa perspectiva, o estudo das práticas discursivas exige uma retomada dos conceitos de condições de produção do discurso (CPD) e de memória.

Tomaremos, aqui, a contribuição sobre a noção de Condições de Produção do Discurso produzida por Courtine (1981, p.53), em sua Tese. “Toda produção discursiva faz circular formulações anteriores, [...] que ela repete, transforma, denega... Isto é: em relação ás quais esta formulação produz efeitos de memória.. Continuando sua reflexão, o referido autor, (Id, p.53), acrescenta, ainda, que "a noção de memória discursiva diz respeito á existência histórica de enunciados no seio de práticas discursivas". É também de Courtine (2006, p.10) a afirmação de que " a linguagem é o tecido da memória, isto é sua modalidade de existência histórica”. A partir daí, podemos concluir que a memória discursiva seria, então, o conjunto de formulações de saberes discursivos que tornam possíveis novos dizeres. Ou seja, ao serem retomadas em novas sequências discursivas, essas formulações produzem diferentes efeitos - de ratificação, redefinição, ruptura, negação - do "já dito".

Outra contribuição sobre as CPD nos é fornecida por Orlandi (2005, p. 30) que trata dessa noção considerando que ela inclui os sujeitos e a situação, apresentando um sentido estrito, ou seja, as circunstâncias da enunciação, o seu contexto imediato e um sentido amplo: o contexto sócio-histórico, ideológico.

Assim, nos é possível afirmar que a questão da análise dos sentidos historicamente determinados encontra na proposição de Orlandi a consideração de uma relação com a memória discursiva que é convocada, operando/ funcionando na produção dos sentidos por meio do trabalho do interdiscurso. Observamos, então, que o processo de discussão da determinação histórica, no campo da $\mathrm{AD}$, exige a análise da relação do discurso 
produzido, num momento histórico específico, com outros discursos com os quais dialoga, retomando-os para repeti-los, refuta-los, enfim (re)significá-los, no jogo contraditório no qual se realiza a articulação entre língua, história e ideologia. É nessa articulação que se constitui a historicidade do discurso, pois "o sentido, para a $\mathrm{AD}$, não está fixado a priori como essência das palavras, nem tampouco pode ser qualquer um: há a determinação histórica" (ORLANDI 2004, p.27). Ou seja, há que se levar sempre em consideração o momento histórico em que se está vivendo, no momento de produção do discurso e a memória que ele convoca. Entendemos aqui, de grande relevância a contribuição de Zandwais (2012) "Se a memória evoca a história, ela somente se concretiza a partir das lembranças que são preservadas na consciência dos sujeitos, do modo como são simbolizadas e, por fim, discursivizadas, tornando-se objetos de diferentes leituras". Assim, ainda segundo a referida autora (Idem)

Ler o acontecimento [...] demanda também penetrar na história, mas tornar-se cético em relação aos sentidos que se cristalizaram na memória e retomar o que foi relegado à ordem do esquecimento, sobretudo quando a ordem do real acaba sendo discursivizada como produto histórico, sendo configurada como estável e despojada de intervenções do sujeito imerso em diferentes conflitos de ordem social.

A partir dessa ótica, neste trabalho, mais do que mapear os acontecimentos discursivos e seus efeitos de interpelação na reformulação parafrástica, o nosso objetivo, ancorado na teoria da $\mathrm{AD}$ e na historiografia marxista, como já dito anteriormente, é analisar como o emergir de processos discursivos, materializados em enunciados que circulam na conjuntura atual do início do século XXI, nos demonstram deslocamentos/ reconfigurações dos blocos de poder, das classes sociais em seu "costurar" do real da história.

\section{0 acontecimento de 15 de março de 2015, no Brasil: condiçães de pro- dução e ecos do bonapartismo.}

Acerca do bonapartismo existe uma vasta produção da literatura marxista com diferentes vertentes e interpretações. Traremos aqui somente alguns aspectos que julgamos consensuais e que, de alguma maneira, nos fornecem contribuições para o entendimento do momento histórico atual. 
Os alicerces teóricos do conceito de bonapartismo foram assentados por Marx, em sua obra O dezoito Brumário de Luís Bonaparte, ao analisar a crise hegemônica concebida nas relações de produção capitalista e pela incapacidade da burguesia e suas facções de manter seu domínio pelas regras constitucionais da República democrática-parlamentar, diante da ameaça de revolução proletária na França em 1851, que resultou no golpe de estado de Napoleão III.

Não podemos deixar de sublinhar também as contribuições de Engels nas análises do regime político prussiano, variante, dotada da particularidade de um capitalismo tardio, em vias de consolidação. Assim, entendido como regime político do Estado burguês, o bonapartismo pode ser caracterizado como "garantidor da integridade nacional" com base na relativa "autonomia do Estado", perante as classes sociais, encarnado num líder (ou instituição), quase sempre carismático, com um poder executivo hipertrofiado, sustentado pelas Forças Armadas. Configura-se, assim, como "uma formatação particular assumida pelo Estado capitalista em momentos de crise, um tipo de regime político caracterizado por uma dominação política indireta da burguesia, sobre as demais classes sociais.", conforme (Demier, 2012 p. 18.). Prosseguindo, o referido autor (Idem, p.19) afirma que a razão de ser do bonapartismo é atacar,

[...] violentamente aquele que é o fundamento primeiro do temor burguês: o movimento operário organizado. Proibindo, fechando ou mesmo destruindo as organizações sindicais, políticas e culturais dos trabalhadores, o regime bonapartista intenta desmontar a vanguarda da classe que, pela sua própria existência, coloca em risco a manutenção da exploração social.

Esse risco começa a dar sinais de alerta, no contexto histórico da América Latina, na década de 60, ante as tensões da guerra fria, o triunfo da revolução cubana e a organização da classe trabalhadora que protagonizava insurreições e mobilizações em massa. No intento de estancar o avanço do processo revolucionário, o imperialismo norte americano, através de seus organismos de espionagem, camuflado por um discurso salvacionista, patrocina golpes militares, com o objetivo de impedir a "comunização" na América Latina.

No Brasil, o golpe militar de 1964 resultou na queda do projeto desenvolvimentista do capitalismo brasileiro, capitaneado pelo nacionalismo trabalhista - PTB - e apoiado por forças populares sindicais/camponesas 
que pressionavam o governo Jango para realização das reformas de base e pela instalação de uma CPI, para investigar os lucros das multinacionais no país. Nos dias que se sucederam ao golpe, as hostes conservadoras organizaram grandes manifestações em "defesa da democracia e da ordem", em "defesa da família", além do apoio incondicional às Forças Armadas que "salvaram o Brasil do comunismo". A mídia falada e impressa também se empenhou em exaltar o "heroísmo das Forças Armadas", como podemos constatar em matéria divulgada pelo jornal O Globo, em 02/04 de 1964, um dia após o Golpe.

\section{"Ressurge a Democracia"}

Vive a Nação dias gloriosos. Porque souberam unir-se todos os patriotas, independentemente de vinculações políticas, simpatias ou opinião sobre problemas isolados, para salvar o que é essencial: a democracia, a lei e a ordem. Graças à decisão e ao heroísmo das Forças Armadas, que obedientes a seus chefes demonstraram a falta de visão dos que tentavam destruir a hierarquia e a disciplina, o Brasil livrou-se do Governo irresponsável, que insistia em arrastá-lo para rumos contrários à sua vocação e tradições. [...] Salvos da comunização que celeremente se preparava, os brasileiros devem agradecer aos bravos militares, que os protegeram de seus inimigos.

Percebe-se, nessa materialidade, a retomada de uma memória discursiva que remonta ao discurso bonapartista. As Forças Armadas como garantidoras da "integridade nacional" em nome da "democracia, da lei e da ordem", depõem "um governo irresponsável" que insistia em arrastar o Brasil para "rumos contrários à sua vocação e tradições", protegendo o Brasil de "seus inimigos". Quais são os rumos e vocações do país que estão em risco nesse momento? O colonialismo dependente, a propriedade privada, a exploração dos trabalhadores. Esses (trabalhadores organizados em sindicatos) assumem o papel de inimigos do país, por se organizarem e tentarem desmontar o sistema de dominação capitalista burguês. Assim, além de silenciar a inconstitucionalidade do golpe, que depõe, pela força, um governo legitimamente eleito, esse discurso criminaliza os movimentos sociais organizados que tentavam, com sua organização, construir uma sociedade menos injusta e desigual.

Ante essa "ameaça", a classe dominante no poder apoia e financia o golpe militar que desencadeia um processo de violência física e simbólica, 
através de seus aparelhos, buscando não somente "fazer calar" os que se opunham ao regime, mas também obrigando "a dizer" apenas o que, era conveniente ao governo. Desse modo, entende-se que o golpe de 64, institui o Estado bonapartista burguês cuja ração de ser, segundo (Demier, 2012 p. 18.), citado anteriormente é "atacar, fechando ou mesmo destruindo as organizações sindicais, políticas e culturais dos trabalhadores" desmontando a vanguarda da classe que, pela sua própria existência, coloca em risco a manutenção da exploração. Dessa forma, no dizer de Zoppi-Fontana (2002, p, 180), o golpe militar empresarial de 64, no Brasil levou à "irrupção do arquivo de sentidos outros que quebram as reformulações parafrásticas estabilizadas como memória, constituindo um acontecimento discursivo que abre espaço para novos processos de significação", ressignificando conceitos como "revolução" "democracia", "liberdade", "cooperação", "patriotismo", etc.

Passados mais de 50 anos do Golpe militar, nos protestos organizados contra o governo Dilma e o PT, ainda percebemos, em discursos produzidos na atualidade, ecos dessa memória. Como já referido anteriormente, $\mathrm{o}$ processo de discussão da determinação histórica, no campo da $\mathrm{AD}$, exige a análise da relação do discurso produzido, num momento histórico específico, com outros discursos com os quais dialoga, retomando-os para repeti-los, refuta-los, enfim, ressignificá-los, no jogo contraditório no qual se realiza a articulação entre língua, história e ideologia. Assim, antes de falar sobre o acontecimento de 15 de março, é necessário caracterizar a conjuntura política na qual ele emerge.

A transição do final dos anos de 1970 e inicio dos anos de 1980 (fim da ditadura - início do processo de redemocratização), desencadeou processos históricos que culminaram com o esgotamento dos regimes bonapartistas militares e a crise das autocracias burguesas na América do Sul, fazendo emergir novas explosões sociais que resultaram em novos rearranjos no bloco hegemônico. Os chamados "processos de abertura política" e a engenharia social dos "novos pactos" mais uma vez, ratificaram as "soluções pelo alto" típicas dos capitalismos de "via prussiano-colonial" reordenando as alianças das frações burguesas nacionais sul-americanas com o imperialismo estadunidense. Os processos históricos abertos com a crise de hegemônica das ditaduras levaram os EUA a reordenarem sua política intervencionista militar, aberta para uma linha de intervenção mais discreta, consequentemente apoiando as "aberturas democráticas", entretanto garantindo a manutenção da dominação econômica via "novas orientações" do FMI e do Banco Mundial, orquestradas no consenso de Washington.

6 Cf. MAZZEO 1988. p. 21-22. 
No Brasil, a implantação das políticas neoliberais e os limites da já restrita democracia burguesa, construída na constituinte de 1988, já resultaram em mobilizações de massas em 1992 que levaram ao impeachment do primeiro presidente eleito pós-ditadura empresarial-militar, Fernando Collor. Entretanto, prevaleceu mais uma vez uma "solução pelo auto" dando mais um "fôlego" á institucionalização da autocracia burguesa de 1988, na esteira do plano real e de relativa estabilidade estruturada no neoliberalismo de dois mandatos do PSDB e no social-liberalismo ou num "reformismo quase sem reformas" do PT que vai iniciando o seu quarto mandato, ambos com uma macropolítica econômica muito parecida.

Os mandatos petistas, principalmente o primeiro do Presidente Lula, de alguma forma, estava em sintonia com os processos políticos que marcaram o ciclo de "governos de esquerda" no inicio do século XXI na América do Sul. Esses mandatos foram caracterizados pelo "pacto de classes" consubstanciado, segundo Iasi (2014, p. 149) "numa política de desenvolvimento econômico que garantisse os marcos necessários para a acumulação de capitais que supostamente levaria ao aumento da arrecadação e á lenta e focalizada transferência para políticas de amenização da miséria extrema”. Somando-se a isso tivemos a cooptação pelo governo, da maioria ${ }^{7}$ dos sindicatos, centrais sindicais, partidos, movimentos sociais, com vistas a um apassivamento de possíveis conflitos. Assim, ainda conforme Iasi (Idem),

Nos termos idealizados do pacto e da democracia de cooptação, todos sairiam ganhando: os trabalhadores, pelo aumento da oferta de emprego (ainda que achatando os salários no topo da pirâmide de assalariados e precarizando direitos e vínculos trabalhistas) e pelo acesso ao consumo, via facilitação do crédito; para aqueles abaixo da linha da miséria absoluta (menos de um dólar por dia), com políticas compensatórias como bolsa família; para os grandes empresários do capital monopolista, além das condições macroeconômicas e o saneamento do Estado, subsídios diretos e "previsibilidade" para fazer seus investimentos e garantir suas taxas de lucro.

No final do primeiro mandato do governo Dilma, o referido "pacto de classes" começa a apresentar sinais de esgotamento. A crise econômica in-

7 Com raras exceções de organizações e grupos revolucionários que optaram e ainda optam por não pactuar com o atual estado de coisas. 
ternacional impõe a redução das taxas de crescimento do país, criando dificuldades para persistir na conciliação do discurso "desenvolvimentista" com a prática neoliberal, o que implica impedimento da manutenção das políticas compensatórias ou de redistribuição de renda, comprometendo as políticas sociais (consentidas). Nesse contexto, as políticas compensatórias reparadoras terão de ser reduzidas, para ampliar as taxas de acumulação do capital. Segundo Santos-Neto (2015, p.7) "Apesar do incentivo fiscal do governo e do rebaixamento do valor da força de trabalho, a indústria brasileira não tem nem mesmo conseguido preservar sua posição no mercado interno, ante a avalanche dos produtos asiáticos." É nesse clima de desaquecimento da economia brasileira, de aguçamento da crise do setor industrial e de denúncias de corrupção que começa a ser gestada a campanha de protestos contra o governo, já em 2013.

A insatisfação recrudesce com o resultado das últimas eleições presidenciais em que, após uma disputa acirrada, a presidente Dilma sai vitoriosa, mas com uma diferença mínima, com relação a seu opositor. Assim, visando ao aprofundamento dos ataques aos interesses da classe trabalhadora é orquestrada uma campanha pelo impeachment da presidente Dilma que culmina com a marcha por um "Brasil livre" cujo slogan foi o "Fora Dilma”, ocorrida em 15 de março de 2015.

Toda a mídia, falada e impressa, mobilizou-se para dar cobertura à marcha que ocorreu em todas as capitais brasileiras, convocada pelo movimento Brasil livre. Esse acontecimento fez eclodir uma infinidade de materialidades discursivas das quais trazemos aqui, apenas algumas que, a partir do nosso gesto de interpretação, mais nos chamaram a atenção por seu conteúdo e pela memória convocada. Iniciaremos pela capa da revista ISTO É, posta em circulação imediatamente após o dia 15.

Chamou nossa atenção, em primeira instância, o título da capa da revista - "O rugido das ruas". Por que não "o barulho", os "protestos", "o movimento" ou até mesmo "a revolta das ruas"? Esses títulos não provocariam o mesmo impacto que a metonímia utilizada em "rugido das ruas". Logo, não foi por acaso a escolha do título da capa da revista. Como dizem Bakhtin/Volochinov (1981, p.36).

[...] A palavra é o fenômeno ideológico por excelência. A realidade toda palavra é absorvida por sua função de signo. A palavra não comporta nada que não esteja ligado a essa função, nada que não tenha sido gerada por ela. A palavra é o modo mais puro e sensível da relação social. 
Vale ressaltar, que os autores não se referem à palavra como uma forma abstrata, como objeto de dicionários, mas como signo, inserido na práxis, logo dotado de valor ideológico. Assim sendo, adquire vida, constituindo a materialidade do ideológico, tornando-se assim o indicador mais sensível das relações sociais, por meio do modo como penetra e se desloca no movimento incessante da luta de classes, de todas as épocas registradas na historiografia. Por essa razão, afirmamos que a escolha da palavra rugido, no título da capa da revista, foi intencional e tem um destinatário certo - o governo. Rugido evoca fúria, ameaça, imprime medo - o rugido da fera pronta para o ataque, o rugido do mar revolto, sacudido por grandes tempestades. O que representa esse rugido? Quem deve temê-lo?

A resposta a essas questões aparece em um enunciado, logo abaixo do título. "A opinião pública se organiza contra o governo e ganha uma força política acima de qualquer partido. A oposição está nas ruas.. Esse enunciado, num jogo parafrástico, retoma enunciados ditos em outro lugar, em 02 de abril de 1964. "Vive a Nação dias gloriosos. Porque souberam unir-se todos os patriotas, independentemente de vinculações políticas, simpatias ou opinião sobre problemas isolados, para salvar o que é essencial: a democracia, a lei e a ordem." Ou seja, os que estão nas ruas, "independente de vinculações partidárias" são os "patriotas", a opinião pública unida, que representa a nação. Os que não estão ali, hoje como ontem, são os "inimigos" que querem arrastar o país "para rumos contrários à sua vocação e tradições."

Ora, se não existe identificação partidária, como a Revista pode afirmar que é a oposição que está nas ruas, se tanto a oposição quanto o governo congregam vários partidos políticos que lhes dão sustentação? Por outro lado, ao afirmar que a oposição está nas ruas, a Revista silencia as marchas de apoio ao governo ocorridas dois dias antes, em 13 de março de 2015, denominada "Sexta-feira 13". Como já foi dito em outro momento por Cavalcante (2012, p. 299) "o discurso é um fazer histórico na medida em que resulta da elaboração de um sujeito histórico [...] que traz em si todas as vozes que o antecederam.” Assim sendo, nenhum discurso nasce da vontade repentina de um sujeito, mas de um trabalho sobre outros discursos com os quais o sujeito se identifica - repetindo, reafirmando - ou se desidentifica - negando ressignificando.

Esse processo de identificação/desidentificação dos sujeitos está impresso em outras materialidades que surgiram nos protestos de rua. Destacamos aqui, apenas algumas que chamam a atenção por seu conteúdo 
fazer ecoar discursos outros, de um acontecimento inscrito na memória histórica do povo brasileiro, há mais de 50 anos.

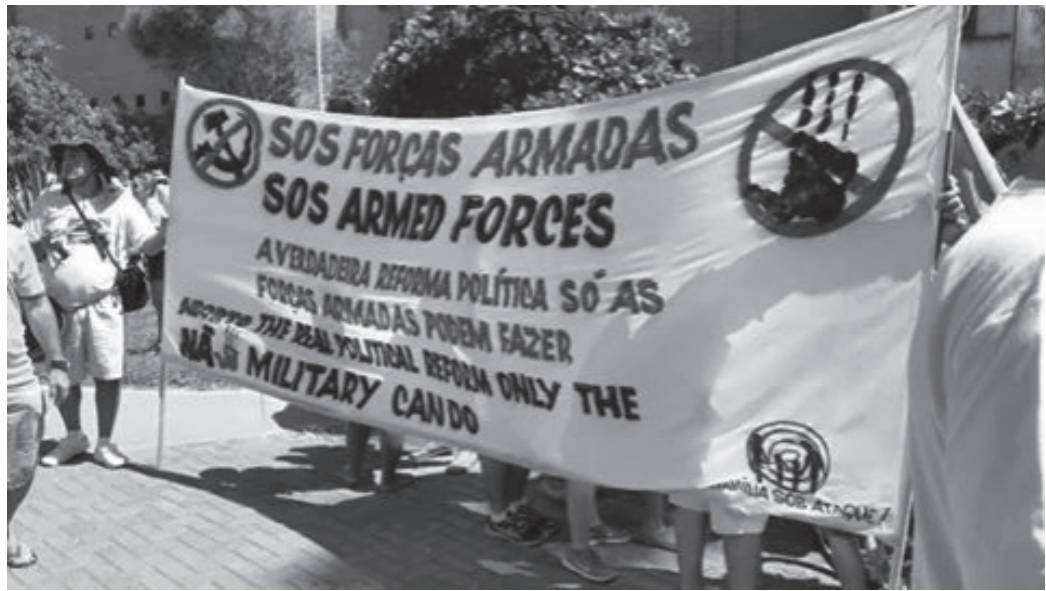

Confrontando as discursividades inscritas nessa faixa, com a matéria do jornal O Globo, de 02 de abril de 1964, (anteriormente referida), é possível perceber a retomada de posições assumidas àquela época.

\section{"Ressurge a Democracia"}

Vive a Nação dias gloriosos. Porque souberam unir-se todos os patriotas, independentemente de vinculações políticas, simpatias ou opinião sobre problemas isolados, para salvar o que é essencial: a democracia, a lei e a ordem. Graças à decisão e ao heroísmo das Forças Armadas, que obedientes a seus chefes demonstraram a falta de visão dos que tentavam destruir a hierarquia e a disciplina, o Brasil livrou-se do Governo irresponsável, que insistia em arrastá-lo para rumos contrários à sua vocação e tradições. [...] Salvos da comunização que celeremente se preparava, os brasileiros devem agradecer aos bravos militares, que os protegeram de seus inimigos.

É essa memória, do discurso bonapartista, que irrompe nas discursividades de 15 de março. Como vemos na faixa exibida, retoma-se o discurso o anticomunismo - materializado no símbolo do partido comunista com o sinal de interdição; o apelo à intervenção das Forças Armadas, como garantia da 
"ordem" - nos enunciados (em português e inglês) "SOS Forças armadas" e "A verdadeira reforma política só as Forças Armadas podem fazer" -; a defesa da família - no símbolo da família com o enunciado: "A família sob ataque" e, por fim, o discurso anti PT e anti Lula, grotescamente representado pela mão com apenas quatro dedos, com o sinal de interdição.

Ao serem retomadas em novas paráfrases, em outra conjuntura, essas formulações produzem efeitos de ratificação do "já dito". Isso é possível pelo movimento do interdiscurso que estabelece a relação do "já dito", em outro lugar, com o que está sendo dito em situações e conjunturas diferentes. Segundo Courtine e Marandin (1981, p. 58),

O interdiscurso consiste em um processo de reconfiguração incessante no qual uma formação discursiva é conduzida [...] a incorporar elementos pré-construídos no interior dela própria; a produzir sua redefinição e seu retorno, a suscitar igualmente a lembrança de seus próprios elementos, organizar sua repetição, mas também a provocar eventualmente seu apagamento.

Como já ressaltado em Cavalcante (2007, p. 49), "Aí se dá o processo de identificação do sujeito que, empreendendo um movimento de retorno à memória discursiva, apropria-se de elementos já ditos, ressignificando-os e transformando-os em objetos de seu discurso." As duas faixas que seguem também reiteram a mesma posição de identificação com o discurso anticomunista, materializado nas sequências discursivas: "Liberdade burguesa sim Socialismo não" e "Diga não à doutrina marxista nas escolas".

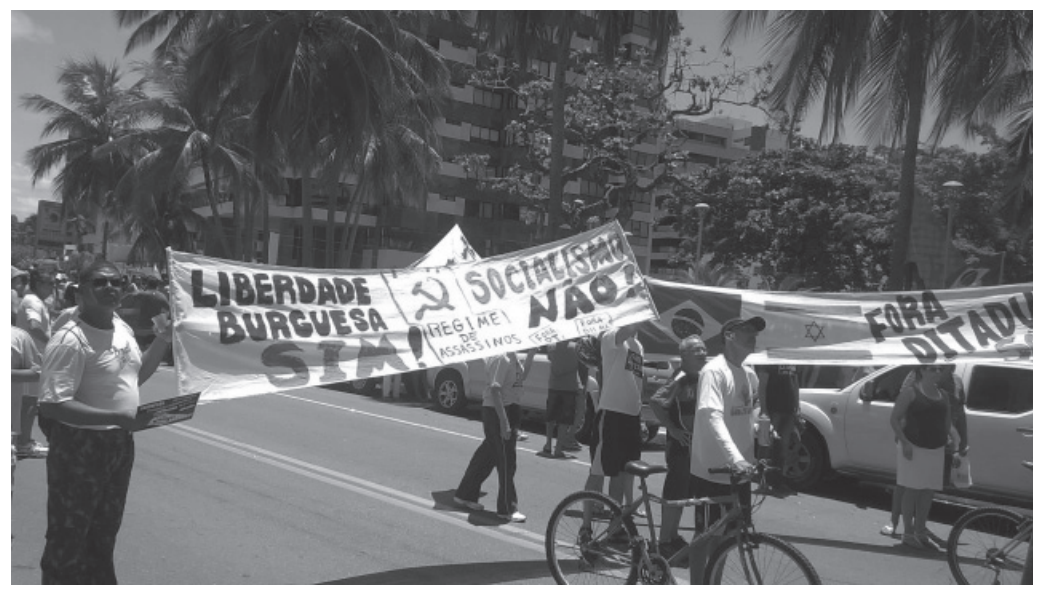

Organon, Porto Alegre, v. 30, n. 59, p. 117-135, jul/dez. 2015. 


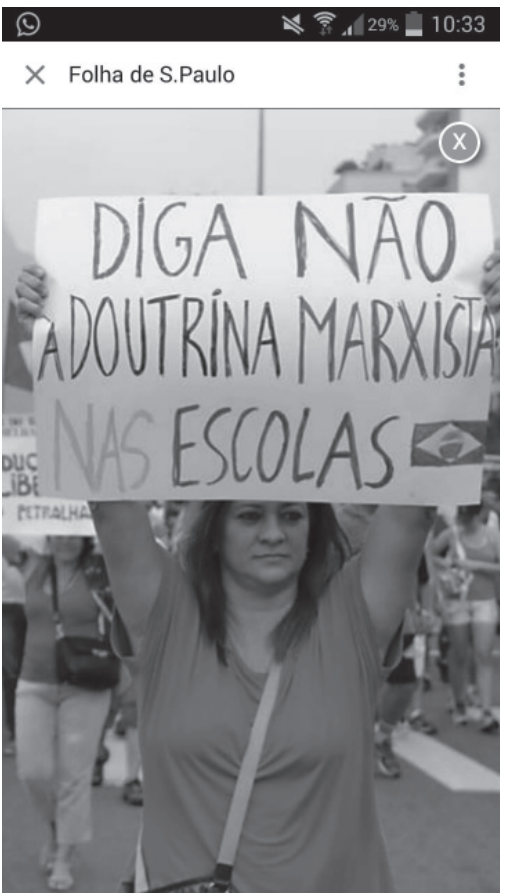

Percebe-se aí, através do processo de ressignificação, a estratégia de homogeneização e de monovalência do signo, utilizada pela classe dominante. Como dizem Bakhtin/Volochínov (1981, p. 46)

Aquilo mesmo que torna o signo ideológico vivo e dinâmico faz dele um instrumento de refração e de deformação do ser. A classe dominante tende a conferir ao signo ideológico um caráter intangível e acima das diferenças de classe, a fim de abafar ou de ocultar a luta dos índices sociais de valor que aí se trava, a fim de tornar o signo monovalente.

É isso que constatamos nas sequências, a hegemonia burguesa, sentindo-se ameaçada pela crise internacional que desaquece a economia brasileira, dificultando a expansão da, resolve atacar as políticas compensatórias resultantes do "pacto social" (consentido), que, de alguma forma, podem representar um obstáculo para a melhoria de condições para a reprodução do capital. Desse modo, aproveitando-se da onda de corrupção que assola 
o país ${ }^{8}$, e, utilizando como cortina de fumaça (o velho) discurso anticomunista, busca o consenso das massas, organizando estratégias para responsabilizar o governo atual por todas as mazelas por que passa o país. Com isso, oculta seus reais interesses - de manutenção da exploração - buscando passar suas verdades, através de um discurso monovalente, que deve ser absorvido por todos. Com esse discurso e com o apoio da mídia, foram organizadas grandes mobilizações de massa que produziram os acontecimentos discursivos analisados. A respeito ainda dessas mobilizações, entendemos ser de grande pertinência o posicionamento de Magalhães e Silva Sobrinho (2014, p.3).

Essas práticas sociais que vêm ocorrendo desde junho de 2013, no Brasil ressaltam a necessidade de se rever arquivos e analisá-los para além de sua imediaticidade. Reafirmam, assim, a teoria marxiana, quando ressalta como única forma de compreender o real da história uma análise que leve em consideração o movimento da própria história em sua totalidade complexa. Isso significa que não podemos isolar a análise de discurso da sua práxis, pois é grande o risco de se abstrair o caráter material do sentido que ali se manifesta e atua dialeticamente nas relações sociais contraditórias.

\section{Considerações finais}

Há que se enfatizar a eficácia dos mecanismos que a classe dominante possui para buscar consensos, a fim de defender seus interesses, fazendo-os passar por interesses coletivos. Finalizando nossa reflexão, entendemos ser pertinente trazer aqui uma citação de Marx, retirada de sua obra $\mathrm{O}$ 18 Brumário de Luis Bonaparte (sd, p.203), que, a nosso ver se aplica aos acontecimentos analisados.

Hegel observa em uma de suas obras que todos os grandes fatos e personagens da história universal aparecem como que duas vezes. Mas esqueceu-se de acrescentar: a primeira vez como tragédia e a segunda como farsa. [...] A tradição de todas as gerações mortas oprime como um pesadelo sobre o cérebro dos vivos.

8 Embora reconheça a importância de uma análise aprofundada dessa questão, não trataremos desse tema, aqui. 
E justamente quando parecem empenhados em revolucionar-se a si e às coisas, em criar algo que jamais existiu, precisamente nesses períodos de crise [...] os homens conjuram ansiosamente em seu auxílio os espíritos do passado, tomando-lhe emprestado os seus nomes, as suas palavras de ordem de combate, a sua roupagem, para, com este disfarce de velhice venerável e esta linguagem emprestada, representar a nova cena da história.

\section{BIBLIOGRAFIA}

ALTHUSSER, Louis. Aparelhos Ideológicos de estado. Rio de Janeiro: Graal, 1985.

BAKHTIN, Mikail \& VOLOCHÍNOV. Marxismo e filosofia da linguagem. São Paulo, 1981.

BAKHTIN, Mikail - Para uma filosofia do ato, traduzido por Carlos Alberto Faraco e Cristóvão Tezza. Versão ainda não revisada, destinada a fins didáticos. 1990

CANDAU, Vera Maria. 2 ed. Ensinar e aprender: sujeitos, saberes e pesquisa. Rio de Janeiro: DP\&A, 2001, p. 175-189.

CAVALCANTE, M. do Socorro Aguiar de Oliveira. "Implícitos e silenciamentos como pistas ideológicas” In: Leitura №. 23 Maceió EDUFAL, 1999.

. Qualidade e cidadania nas reformas da educação brasileira; o simulacro de um discurso modernizador. Maceió: EDUFAL, 2007.

COGGIOLA, Oswaldo. Governos militares na América Latina. São Paulo: Contexto, 2001.

DUARTE, Newton. Educação e moral na sociedade capitalista em crise. In: - A rendição pós-moderna à individualidade alienada e a perspectiva marxista da individualidade livre e universal. In: DUARTE, Newton (Org.). Crítica ao fetichismo da mercadoria. Campinas, São Paulo: Autores Associados, 2004, p. 219-242.

FLORENCIO, Ana Gama et all. Análise do discurso: fundamentos e práticas. Maceió: EDUFAL, 2009.

GASPARI, Elio. Ditadura envergonhada. São Paulo, Companhia das Letras, 2002.

GRAMSCI, Antonio. Cadernos do cárcere. $2^{\text {a }}$ Ed. Rio de Janeiro, Civilização Brasileira, Vol. 1 e 2, 2001.

HOBSBAWM, Eric. Sobre História. São Paulo: Companhia das Letras, 2002. 
IASI, Mauro. As manifestações de massa e a dimensão estratégica. In: SAMPAIO JR., Plínio de Arruda (Org.). Jornadas de Junho - Revolta popular em debate, ICP, São Paulo, junho de 2014. MARX, Karl e ENGELS, Friedrich, Obras escolhidas. São Paulo; Editora Alfa-omega, s/d.

MAZZEO, A. C. Burguesia e Capitalismo no Brasil. Ed. Ática, São Paulo, 1988.

MÉSZÁROS, István, O poder da ideologia. São Paulo; Boitempo, 2004. . O SÉCULO XXI - socilaismo ou barbárie ?. São Paulo; Boitempo, 2003.

. A educação para além do capital. São Paulo; Boitempo, 2006. Para além do capital. São Paulo; Boitempo, 2004.

ORLANDI, Eni. Análise de Discurso princípios \& procedimentos. Campinas, Pontes, 1999. As formas do silêncio no movimento dos sentidos. Campinas: Editora da Unicamp, 1993. Discurso em Análise: Sujeito, Sentido e Ideologia; 2a Ed. Campinas, SP: Pontes Editores, 2012.

Discurso e Texto: formulação e circulação dos sentidos; Campinas, SP: Pontes Editores, 2001. PÊCHEUX, Michel. Semântica e discurso. Trad. de Eni Orlandi. $3^{\text {a ed. }}$ Campinas, Pontes, 1997.

. O Discurso: Estrutura ou acontecimento. Campinas: Pontes, 1990. Textos selecionados: Eni Orlandi. 4aed. Campinas, Pontes, 2014. Análise de Discurso: Michel Pêcheux.

REIS, José Carlos. História, a ciência dos homens no tempo. Londrina: EDUEL, 2009.

SILVA SOBRINHO, Helson Flávio. Discurso, velhice e classes sociais: a dinâmica contraditória do dizer agitando as filiações de sentidos na processualidade histórica. Maceió: Edufal, 2007. TROTSKY, Leon. A Revolução Traída: O que é e para aonde vai a URSS. São Paulo: Editora Sundermann, 2005. VAISMAN, Ester. A ideologia e sua determinação ontológica. In Ensaio, São Paulo, n¹7/18, 1989.

ZANDWAIS, Ana. Ler o acontecimento. Memória nacional e construção identitária no Estado Novo: formas de significar o sujeito imigrante através de dispositivos jurídico-políticos. Teorias e práticas de leitura. São Paulo: Ed. terracota, 2012.

Recebido em: 05/06/2015. Aceito em: 21/07/2015. 